\title{
WHO PROVIDES CORPORATE SOCIAL RESPONSIBILITY (CSR) ASSURANCE AND WHAT ARE THE IMPLICATIONS OF THE VARIOUS ASSURANCE PRACTICES?
}

\author{
Barry Ackers* \\ University of South Africa \\ ackerb@unisa.ac.za
}

Received: March 2013

Accepted: January 2014

\begin{abstract}
Independent assurance improves the credibility of corporate social responsibility (CSR) disclosures by providing stakeholders with confidence about the veracity of CSR disclosures and attempts to ameliorate the risk of unscrupulous companies falsely reporting their CSR performance. This article establishes the prevalence of CSR assurance by the 200 largest JSE-listed companies for the period ended 2011/2 (the year after King III became effective), in terms of the assurance provider, the assurance standards, the assurance report components and assurance opinions. Within this context, this article specifically focuses on the role of the audit profession. The article concludes that the rate of growth in CSR assurance by auditors is surpassed by that of non-auditor assurance providers. Whereas reporting companies may use auditors for CSR assurance due to the perceived credibility and strong brands of the auditing profession, enhanced by rigorous assurance methodologies, they may use non-auditor assurance providers due to the higher assurance levels provided and reduced costs.
\end{abstract}

Keywords

Assurance characteristics, assurance liability, assurance opinions, audit profession, assurance standards, assurance reports, corporate social responsibility, King III

*Mr B Ackers is a senior lecturer in the Department of Auditing, University of South Africa, Pretoria, South Africa. 


\section{INTRODUCTION}

In 1970 Friedman argued that the social responsibility of business was to use its resources in activities that would increase profits, while operating within the predefined rules and norms established by society. Freeman (1994:413), however, posits that business theories are inconsistent with shareholder primacy, with stakeholder theory providing a better normative fit. Stakeholder theory essentially holds that business is responsible to various groups in society that may have a claim, ownership, rights or interest in a company and its activities, whether in the past, the present or the future (Freeman, 1994), while simultaneously achieving its business objectives (Blair, 2005:33). Despite providing shareholders with a return on investment, it can be argued that companies contribute to the social agenda, albeit indirectly, by creating employment opportunities, stimulating the economy and uplifting dependent neighbouring communities (Freeman, 1994:411).

As stakeholders begin to hold companies accountable for the non-financial impacts of their operations (albeit unintended), it is increasingly being recognised that corporate accountability extends beyond shareholders, and includes other stakeholders as well. The demand for increased corporate accountability is exacerbated by the combined pressures of anthropogenic climate change (Kirk, 2008) and a burgeoning global population and global recession (Manwaring \& Spencer, 2009). Companies are responding to stakeholder demands to reduce the adverse impact of human activity on society and the environment by disclosing the consequences of their actions, or inactions, on society and the environment (CorporateRegister, 2008:5).

In order to opportunistically capitalise on the positive association with strong CSR performance, unscrupulous companies may be tempted to make false claims about their CSR performance. In CSR, this 'window dressing' is referred to as 'green-wash' (Alves, 2009; Aras \& Crowther, 2008; Delmas \& Burbano, 2011; Lyon \& Maxwell, 2011; Okoye, 2009:624; Polonsky, Landreth \& Garma, 2010). Green-wash or 'linguistic hijacking' is the cynical intention to deceive by selectively disclosing CSR-related information. Companies disclosing CSR information may therefore not necessarily be good corporate citizens, but may simply want to favourably influence stakeholder perceptions (Aras \& Crowther, 2008; Okoye, 2009:624; Teoh \& Shiu, 1990:75). Aras and Crowther (2008) argue that even the language used in CSR reports may be designed to influence thought and divert attention away from the corporate reality.

The need for independent CSR assurance that enhances the perception about the integrity and credibility of CSR disclosures has been established by several authors (Adams \& Evans, 2004; Al-Hamadeen, 2007; Gouws \& Cronjé, 2008; Marx \& van Dyk, 2011; Mitchell \& Hill, 2010) and is discussed in this article in the context of the intended audiences.

\section{LITERATURE REVIEW}

\subsection{Corporate social responsibility (CSR)}

CSR remains a relatively contentious global issue (Aras \& Crowther, 2008), with stakeholders increasingly expecting companies to act responsibly and sustainably. Despite society increasingly demanding that companies should account for the adverse impacts of their operations, at the same time CSR provides an opportunity that proactive companies may capitalise upon. 
CSR represents the 'decisions and actions taken for reasons at least partially beyond the firm's direct economic or technical interest' (Davis, 1960:70-71). Companies therefore not only have economic and legal obligations, but also certain societal responsibilities extending beyond these obligations, by including the narrow corporate economic, technical and legal dimensions (Davis, 1973:312-313; Ramasamy \& Yeung, 2009). Ultimately, CSR may be defined as the obligation for companies to use their resources in ways that benefit society through committed participation as a member of society, and taking account of the interests of society at large, by improving the welfare of society, independently of direct benefits accruing to the company (Kok, van der Wiele, McKenna \& Brown, 2001:287). CSR represents the voluntary adoption of the principles of social responsibility; processes of social responsiveness evident in policies, programmes; and observable outcomes relating to the reporting company's societal relationships (Orlitzky, Schmidt \& Rynes, 2003:403; Williams \& Zinkin, 2008:211; Wood, 1991:693). According to Davis (1973:313), CSR "begins where the law ends", with socially irresponsible companies merely complying with prescribed minimum legal or regulatory requirements.

Stakeholders therefore require balanced financial and non-financial company information, enhanced by independent assurance to ameliorate the effect of corporate green-wash. A lack of confidence in the reporting company's sincerity and the data provided produces a credibility gap between stakeholders and companies (Owen \& O'Dwyer, 2004:1). In order to improve stakeholders' ability to interpret, accept and compare CSR performance, it is suggested that CSR behaviour should be authentically quantified, measured and evaluated against universally accepted benchmarks, standards and principles. In this regard, CSR assurance adds value to CSR disclosures by attesting to their completeness, validity, accuracy, reliability and relevance. Despite the emergence of variations in approach, different forms of assurance opinions and poor disclosure credibility, independent assurance helps to bridge the credibility gap in CSR reports (Al-Hamadeen, 2007:16-17; CorporateRegister, 2008:10; ICAEW, 2004:90; Manetti \& Toccafondi, 2012).

\subsection{CSR assurance}

Assurance is a relatively new term used to describe broader verification processes, including audit, validation, review and attestation (Al-Hamadeen, 2007:21-22). Despite being interchangeably used, in this article, the terms assurance, assure and assuror are used to refer to non-financial information, whereas auditing, audit and auditors relate to financial information or to members of the auditing profession. The essential components of assurance include independence; a clear auditable subject; examining documentation and gathering evidence; and issuing an opinion based on the evidence obtained (Al-Hamadeen, 2007:63). In CSR, the term 'assurance' is preferred to 'audit' since it conveys a lower level of endorsement (Owen \& 0'Dwyer, 2004:6). Independent assurance provides users with confidence about the veracity of the engagement subject matter (F\&E, 2003). The International Auditing and Assurance Standards Board's (IAASB) International Framework on Assurance Engagements (IFAE) defines an assurance engagement as being one that expresses an opinion aimed at enhancing user confidence about the overall evaluation of CSR performance (IIA, 2010:7) against specific criteria (SAICA, 2008:Frame-3). CSR assurance facilitates balanced corporate reporting and provides confidence about the completeness, validity, relevance and integrity of CSR disclosures. CSR assurance refers to the entire process through which companies determine and measure their non-financial impacts, and report thereon to broader stakeholders (Owen, Swift, Humphrey \& Bowerman, 2000:85). 
Despite considerable variations in assurance practice, CSR assurance represents the risks to which companies may be exposed and what society is prepared to trust (Al-Hamadeen, 2007:58). While CSR assurance practice may still be in the formative stages, it is evolving rapidly, with stakeholders increasingly relying on assurance to improve the credibility and transparency of CSR disclosures (Kolk \& Perego, 2010:183).

\subsection{CSR assurance prevalence}

Despite broadly mirroring CSR reporting growth (Al-Hamadeen, 2007:51), CSR assurance is developing at different rates across various regions and sectors (Ackers, 2009; CorporateRegister, 2008:12). The demand for voluntary CSR assurance is greater in countries with weaker legal regimes, where assurance serves as a substitute for regulation or legislation (Kolk \& Perego, 2010:186). Even though there is presently no legal requirement to do so, the demand for, and accordingly provision of, independent CSR assurance is growing (ICAEW, 2008:5-6), albeit at a slower rate than CSR reporting (Eccles, Krzus \& Watson, 2012:162). Various authors have found that most companies still do not have their CSR disclosures assured, with compliant companies tending to be larger and in the private sector (Ackers, 2009; Al-Hamadeen, 2007; CorporateRegister, 2008:32; Deloitte, 2012:52; Manetti \& Becatti, 2009; McAusland \& Fogelberg, 2010; Nitkin \& Brooks, 1998:1500).

The provision of CSR assurance is expected to accelerate in South African after the implementation of the ostensibly voluntary King Code of Governance for South Africa 2009 (King III), and especially the Johannesburg Stock Exchange (JSE) regulation compelling JSE-listed companies to apply King III on an 'apply or explain' basis (IoD, 2009; JSE, 2011).

\subsection{CSR assurance providers}

There is presently no consensus about what CSR assurance entails, the competencies they should possess, or even who should undertake CSR assurance engagements (Al-Hamadeen, 2007:133). Al-Hamadeen (2007:22) posits that CSR assurance may be categorised as being either substantiated or unsubstantiated. Substantiated assurance requires a qualified and objective assuror to systematically and formally evaluate and verify the engagement subject matter and report on the engagement results. By contrast, in unsubstantiated assurance, using their experience or expertise, assurors perform a subjective but detailed evaluation of the underlying performance measurement and management processes.

Globally, studies have found that the primary providers of CSR assurance are certification bodies, consultants and auditors (0'Dwyer, Owen \& Unerman, 2011:32). In a study of 650 global CSR assurance reports, CorporateRegister (2008:28) found that the primary assurors were the Big 4 audit firms (40\%), certification bodies (25\%) and consultants (24\%). Similarly, Manetti and Becatti (2009:293) revealed that the Big 4 firms produced $71 \%$ of assurance reports, with the remaining $29 \%$ being issued by other unnamed assurors. In a South African study, Ackers (2009:12) reported that the Big 4 firms produced $80 \%$ of CSR assurance reports, with the remaining $20 \%$ being provided by specialist CSR consultants. By contrast, Al-Hamadeen (2007:134) found that auditor assurors issued only 20\% of CSR assurance reports in a UK-based FTSE100 study, compared to $69 \%$ by consultants and $11 \%$ by certification bodies. To differentiate between the primary CSR assurors, this article uses 'auditor assuror' to refer to public audit firms usually engaged in financial statement audits (Ackers, 2009:5), whereas 'nonauditor assuror' generically refers to other assurors. 


\subsubsection{Consultants and certification bodies}

Consultants and certification bodies are diversifying their operations to include CSR assurance (Jenkins, 2001:15). While specialist CSR consultants may provide greater levels of assurance and add more value to the CSR reporting process, consultants could potentially compromise their independence by including recommendations for process improvement (0'Dwyer \& Owen, 2005:71-72). It is however argued that their assurance processes may not be very rigorous, often relying on information obtained from management, with perfunctory walk-through inspections, and potentially depicting a false situation (Jenkins, 2001:15-16).

\subsubsection{Auditing profession}

Although both internal and external auditors may be considered to represent the audit profession, this article considers external audit firms in public practice and internal auditors separately. The primary objective of an external audit is providing external stakeholders (primarily shareholders) with independent assurance on the reliability of the primarily financial disclosures contained in the annual financial statements (AFS) (Brown, 1962; Jackson \& Stent, 2012; Peecher, Solomon \& Trotman, 2010; Porter, Simon \& Hatherly, 2003). By contrast, the objective of internal audit is assisting internal company stakeholders (management and the board) to achieve the objectives of the company. In this regard, internal audit usually provides top management and the board with independent assurance that all material risks have been identified and are being effectively mitigated within the company's risk appetite (Cascarino \& van Esch, 2007: 5).

While auditors are traditionally associated with providing shareholders with a report expressing an opinion about the veracity of the AFS (Brown, 1962:73), there is a growing requirement for independently verified non-financial company information (Dando \& Swift, 2003; Percy, 1997). Assuring CSR disclosures assists auditors to bridge the 'expectation gap' between the public's expectation that audit reports should cover the entire annual report and the auditors' perspective about their real responsibilities (Haniffa \& Hudaib, 2007:180; Lin \& Chen, 2004; Manetti \& Becatti, 2009; Percy, 1997:4-9). Financial disclosures tend to be perceived as being more credible than non-financial disclosures, since the former are usually audited whereas the latter are usually not (Gouws \& Cronjé, 2008:127).

The services provided by public audit firms are evolving away from focusing only on financial audits, to increasingly providing consulting and assurance services (Maury, 2000:118). Despite still emphasising AFS verification (Porter, Simon \& Hatherly, 2003:7), the auditing profession's business model is changing: it is increasingly depending more on non-financial information often performed by non-chartered accountants, as illustrated by the revenue streams of audit firms now including tax planning, internal auditing, consulting services, information systems and human resource recruitment. CSR assurance represents a new market opportunity for the audit profession (ICAEW, 2004:97). Ashbaugh (2004:145) found that non-audit service fees represent $32 \%$ of audit firm revenues. Auditors have two CSR responsibilities: firstly, to identify CSR-related issues impacting the AFS; and, secondly, to provide assurance over management's CSR disclosures (Percy, 1997).

Building on the rigour of the IAASB Framework and ISAE 3000, and by working with other disciplines, the Institute of Chartered Accountants in England and Wales (ICAEW) (2004:5) argues that auditors are pre-eminently qualified to provide CSR assurance. Complying with rigorous ethical standards, using a clearly defined assurance engagement framework and 
standards, and having the necessary skills and expertise to perform the assurance engagement, auditors enhance CSR report credibility (ICAEW, 2008:6). However, while stakeholders believe that auditor responsibilities should extend beyond AFS attestation and have an obligation to protect the interests of broader stakeholders, the audit profession's efforts still presently focus almost exclusively on financial auditing (Percy, 1997:5).

Auditors are usually more conservative than other assurors by focusing on information consistency in CSR reports, whereas other assurors tend to focus more on completeness, fairness and overall balance (0'Dwyer \& Owen, 2005:225). Auditors cautiously provide lower assurance levels, whereas consultants more liberally provide higher assurance levels (Wiertz, 2009:7).

\subsection{Assurance standards and frameworks}

Assurance standards should provide a consistent platform and utilise common terminology, facilitating comparability and reducing report user confusion (Al-Hamadeen, 2008:32; Owen et al., 2000:91-92). Despite the emergence of several CSR assurance standards and approaches, none are universally accepted (ICAEW, 2008:12). However, since financial audit models inadequately evaluate the robustness of qualitative non-financial CSR dimensions, the value of extant CSR assurance practice remains questionable (Dando \& Swift, 2003:195). While some assurors may use professional engagement standards, developed through rigorous, independent and transparent processes, others tend to rely on subjective judgement to determine the nature, timing and extent of assurance procedures and accordingly the content of CSR assurance reports (IFAC, 2006:7).

Despite the lack of a uniform CSR assurance standard, two dominant approaches have emerged: AA1000AS and ISAE 3000, both underscored by risk (Ackers, 2009:6; CorporateRegister, 2008:12; Manetti \& Becatti, 2009:289; Marx \& van Dyk, 2011:43-44). It is proposed that disclosing information about the standards and guidelines used during the assurance engagement helps users to understand the nature and extent of assurance provided (Al-Hamadeen, 2007:148). Although CSR assurance reports increasingly refer to the GRI Guidelines, these do not represent either a standard or a benchmark against which assurors should measure CSR reports (CorporateRegister, 2008:8\&13). Variations in CSR assurance standards may exacerbate user confusion when assurors combine different heterogeneous operating instruments, even possibly mixing conflicting guidelines and standards (Manetti \& Toccafondi, 2012). Until CSR assurors agree on what assurance should entail and how it should be communicated, simply because a CSR report has been independently assured does not mean that the scope and quality of the assurance engagements are comparable (CorporateRegister, 2008:6).

\subsubsection{ISAE 3000}

Auditor assurors are compelled to comply with the mandatory IFAC Code of Ethics, which includes important provisions relating to competence, due care and objectivity, and which is underpinned by the framework for financial auditing standards (Al-Hamadeen, 2007:39; ICAEW, 2004:92). Auditors performing CSR assurance engagements are therefore obliged to apply ISAE 3000, which is a generic non-financial assurance standard that provides auditor assurors with the necessary guidance on the assurance principles and procedures, including the need for understanding the requirements of intended assurance report users (Al-Hamadeen, 2007:27; ICAEW, 2008:18; Manetti \& Becatti, 2009).

ISAE 3000 provides for short-form (i.e. listing basic elements), or long-form (i.e. including 
additional items such as terms of engagement and findings) assurance reporting and introduces two assurance levels based on the engagement risk (Al-Hamadeen, 2007:28-31; CorporateRegister, 2008:20). In this regard ISAE 3000 provides for both limited and reasonable assurance engagements and opinions. Limited assurance opinions should be expressed in the negative form, implying that insufficient work was performed to allow the assuror to conclude that the CSR report reliably represents company CSR performance (Manetti \& Becatti, 2009). However, limited assurance opinions may conceal the actual engagement work performed and the extent to which stakeholder concerns were addressed, undermining their usefulness to potential users (0'Dwyer et al., 2011:44). Negative-form reports are usually worded in a manner indicating that nothing came to the assuror's attention to conclude that the reported data did not reflect actual performance (Ackers, 2009:6, 11-13; Manetti \& Becatti, 2009:290-297; Marx \& van Dyk, 2011:43-45). By contrast, reasonable opinions should be expressed in the positive form, indicating that sufficient work was done allowing the assuror to conclude that the reported data reasonably reflected company performance. To put it simply, positive-form assurance opinions may indicate that 'the company did it correctly', whereas negative-form opinions may mean that 'nothing leapt out at the assuror as being terribly wrong' (Eccles et al., 2012:1630).

Without specifically advocating multiple assurance levels, ISAE 3000 does not prevent assurors from providing different assurance levels for various aspects of the CSR report, therefore reflecting different verification procedures (Manetti \& Becatti, 2009). However, disclosing multiple assurance levels in the assurance report may increase report user confusion, which could be overcome by the assuror providing limited assurance on the entire report (FE\&, 2011). Despite auditor assurors being more likely to provide limited assurance than non-auditor assurors (Ackers, 2009:12; Manetti \& Becatti, 2009; Marx \& van Dyk, 2011:43-45), the rigorous assurance methodology deployed by auditor assurors, together with its strict application of assurance standards and inherent conservatism, may actually enhance the credibility of CSR assurance reports issued by auditor assurors.

\subsubsection{AA1000AS}

AA1000AS is the only internationally recognised standard specifically designed for CSR assurance (AccountAbility, 2008; Al-Hamadeen, 2007:44), and tends to be favoured by nonauditor assurors. Being principles-based, AA1000AS provides the necessary flexibility for application in different organisations and sectors (CorporateRegister, 2008:8-21). By contrast to ISAE 3000, which was developed specifically for the auditing profession, AA1000AS is intended for use by all CSR assurors (Manetti \& Becatti, 2009). AA1000AS complements the GRI principles (AccountAbility, 2008:19) and is the only assurance standard that effectively aligns assurance with the material interests of stakeholders (Al-Hamadeen, 2007:45-50). AA1000AS requires assurors to evaluate and provide an inclusive opinion on the extent to which the reporting company has adhered to the fundamental principles of inclusivity, materiality, completeness and responsiveness (AccountAbility, 2008:18). Unlike ISAE 3000, AA1000AS specifically recognises that different subject matter may be accommodated in one CSR assurance engagement, with high levels of assurance provided for some aspects of the assurance engagement and moderate assurance levels for others (AccountAbility (2008:10-11). High assurance levels require assurors to gather extensive evidence from internal and external sources, whereas moderate assurance levels are usually associated with gathering limited evidence from internal sources, and focusing on the plausibility of the CSR disclosures. 


\subsection{CSR Assurance characteristics}

To understand the type of CSR assurance provided by the various CSR assurors, it is appropriate to consider the primary components of extant CSR assurance reports. A CSR assurance report involves more than a statement commenting on disclosed CSR performance; it should also refer to the underlying processes and systems generating the CSR data (Al-Hamadeen, 2007:2-17). Reported CSR information should therefore be recorded, compiled, analysed and disclosed in a manner that facilitates providing assurance on the veracity of the CSR data. CSR assurance utilises both quantitative and qualitative techniques to verify the integrity of CSR data (Morimoto, Ash \& Hope, 2005:316). Procedures deployed during CSR assurance engagements include interviews, compliance tests, substantive tests and analytical procedures, incorporating procedures that critically analyse historical data, indexes and business trends; enquiring into gaps between planned and achieved performance (Al-Hamadeen, 2007:133). The assurance opinion expressed by the assuror about the veracity of CSR disclosures requires assurors to gather sufficient and appropriate evidence about the reliability and relevance of the underlying CSR systems and indicators (Morimoto et al., 2005:318).

While the assurance reports produced by the leading CSR assurors may address important principles such as completeness, materiality and accuracy; application is inconsistent, with some assurors simply stating that the underlying systems were checked, or referring to some other limited aspect of the CSR report (Ackers, 2009; CorporateRegister, 2008:6; Manetti \& Becatti, 2009). The assurance framework used should assess the extent to which a CSR assurance engagement includes the following criteria (Al-Hamadeen, 2007:22, 34):

- the engagement subject matter;

- the evaluation criteria;

- a tripartite relationship between the reporting company, the intended report user and the assuror;

- an assurance process, as regulated by standards and against predetermined criteria;

- an assurance opinion; and

- communication of the results of the assurance engagement to users.

However, before stakeholders may be provided with meaningful CSR assurance, appropriate assurance methodologies should be developed; CSR assuror skill sets should be expanded; issues relating to the legal liability of the reporting company and the CSR assuror should be considered; and shareholders should be willing to spend potentially large amounts of money on CSR assurance engagements (Eccles, 2010:vii). To meaningfully account for stakeholder interests, CSR assurors are expected to go beyond normative auditing, by commenting on performance features that are not usually covered in financial audits (Swift \& Dando, 2002). Unlike conventional 'audit reports' about the veracity of the highly regulated and reasonably comparable AFS, the same does not apply to non-financial information or its associated assurance reports.

Independent CSR assurance reports should: refer to the objectives and scope of the assurance engagement; comment on the respective responsibilities of management and assurors; disclose the assurance methodology utilised; provide an opinion on the completeness and fairness of the report; and include recommendations for improvements (ICAEW, 2004:90). By providing performance relevant information, CSR disclosures should facilitate stakeholder decisionmaking. As a result, CSR reports and CSR assurance reports should therefore be addressed to 
stakeholders (Dando \& Swift, 2003:199). However, since many of the terms used in CSR and CSR assurance reports tend to be ambiguous (Aras \& Crowther, 2008; Kirdahy, 2007; Perego, 2009:415; Votaw, 1972:25), report users may experience difficulty to comprehend and appreciate the nature, purpose, scope, and precise meaning of the assurance opinion provided.

\subsubsection{Assurance provider competencies}

Auditors are required to maintain the necessary levels of professional knowledge and skill necessary to deliver a competent service, which is compliant with legislation, regulations and adheres to technical and professional standards (SAICA, 2010:15). Similarly, AA1000AS requires assurors to only accept engagements for which they possess the requisite competencies, making it appropriate to disclose assuror competencies (AccountAbility, 2008:15).

Al-Hamadeen (2007:134) suggests that reporting companies may prefer using auditor assurors (especially the Big 4 audit firms) for their CSR assurance engagements when the assuror's professional reputation and integrity are considered to be important. However, since auditor assurors may lack the necessary time, autonomy or skills to appreciate the dynamics of the CSR phenomenon (Utting, 2005:3; Manetti \& Becatti, 2009), new competencies should be developed (Al-Hamadeen, 2007:15), through a combination of education, training (Percy, 1997:9) and experience (Owen et al., 2000:92). The present conventional accounting and auditing curricula provided by South African universities do not adequately equip students to deal with the inherent ambiguity of non-financial assurance (Gouws \& Cronjé, 2008:128).

\subsubsection{Assurance provider independence}

Independence, an imperative characteristic underpinning the auditing profession (AlHamadeen, 2007:63), may be defined as the objective discharge of responsibilities, free from influence, persuasion or bias (Maury, 2000:118). Stakeholder concerns about assuror independence and objectivity undermine efforts to provide impartial assurance (Chandler \& Edwards, 1996:15), impairing assurance report credibility (Wiertz, 2009:28). An independent expert providing an assurance opinion about the reliability of the underlying disclosures reinforces stakeholder trust in the credibility of the disclosures and is an indicator of assurance quality (Al-Hamadeen, 2007:164-166; ICAEW, 2008:17).

While King III requires companies to provide independent assurance on their CSR disclosures, it does not clarify what constitutes independence. Whereas ISAE 3000 requires assurors to indicate their independence in the assurance report title, AAl000AS requires assurors to disclose their independence in the assurance report body (CorporateRegister, 2008:21). Whereas Deegan, Cooper and Shelly (2006:367) found that few assurance reports disclosed the assuror's independence, Al-Hamadeen (2007:165) found that $56 \%$ of assurance reports explicitly referred to the assuror's independence. Since the assurance reports in these studies probably referenced ISAE 3000 and/or AA1000AS, it is clear that the requirement to disclose independence was not consistently applied.

\subsubsection{Assurance report addressee}

Mitchell and Hill (2010:72) contend that stakeholders, and not only investors, are entitled to assurance on the CSR disclosures in the annual report. These assurance reports should be prepared according to the same standard as for the AFS. While financial audit reports are intended for, and accordingly addressed to, shareholders, CSR assurance reports should be 
produced for the broader stakeholders, but are not necessarily addressed to them (Wiertz, 2009:22; Ackers, 2009). Wiertz (2009:20-21) argues that the CSR assurance report should clearly identify the party or parties for whom the report is intended. For the accounting profession, International Standard on Auditing ISA 700 requires AFS audit reports to be addressed to those for whom the report is prepared. While International Standard on Assurance Engagements ISAE 3000 rather vaguely suggests that the assurance report should be addressed to all intended users, section 49(b) requires the assurance report to identify all possible users. Unlike AFS audit reports, where legislation requires audit reports to be addressed to shareholders, no similar obligation exists for CSR assurance reports (Al-Hamadeen, 2007:142-144).

\section{RESEARCH APPROACH AND METHODOLOGY}

Normatively, stakeholders expect companies to act responsibly about their non-financial impacts. Stakeholders, however, require assurance about the veracity of non-financial corporate disclosures. The objective of this study is therefore to explore and understand extant South African CSR assurance practices (i.e. whether it is being provided, and, if so, by whom, and according to which standards, guidelines and frameworks).

The study utilises a qualitative paradigm to establish the extent to which independent CSR assurance is provided through a phenomenological study of the annual reports of the 200 largest JSE-listed companies (based on market capitalisation) for the reporting period ended 2011/2. Within this context, the characteristics of prevailing CSR assurance practices are reviewed through a content analysis of extant CSR assurance reports. The content analysis reviewed the characteristics of the published CSR assurance reports of the selected companies from the perspective of the assurance approach; assurance methodology, standards and frameworks; scope; types of assurors; and the meaning of the different assurance levels and opinions provided. The exploratory nature of this research is contextualised though the use of relevant secondary data from other studies.

Since this research specifically considers the characteristics of independent CSR assurance within a King III context, and given that the JSE regulations require JSE-listed companies to adopt the King III principles, it is appropriate to confine this study to a purposive nonprobability sample (Welman, Kruger \& Mitchell, 2011:69) representing the largest JSE-listed companies. Moreover, slack resource theory simplistically holds that larger companies are more likely to have the necessary resources and capacity to report on their CSR activities and to provide independent CSR assurance (Bansal, 2005; Eccles, Pillay \& de Jongh, 2008; KPMG, 2011:11; Mill, 2006; Saleh, 2009).

On 30 April 2012, there were 376 companies listed on the JSE, with a total market capitalisation of R6889 billion. Despite representing only $53 \%$ of JSE-listed companies, the largest 200 JSElisted companies accounted for $99 \%$ of JSE total market capitalisation. The selected research sample of 200 companies was reduced to 192 companies, since one company was subsequently delisted and seven companies incorporated their various corporate reports into the annual reports of their holding companies. While this research explores the broad characteristics of extant CSR assurance practices, the selection of a non-representative sample implies that the research observations and conclusions are confined to the sample companies only, and are not generalisable to all South African companies.

The significance of this study is that even though JSE-listed companies are required to apply the 
King III principles, which include providing independent assurance on CSR disclosures (JSE, 2011), this study was done in the first year after the implementation of King III. As such, the observations establish a benchmark against which the rate of growth of CSR assurance can be measured.

\section{CONCEPTUAL DISCUSSION AND ANALYSIS OF THE EMPIRICAL OBSERVATIONS}

Although Ackers (2009) reported that 15\% of the top 100 JSE-listed companies provided independent CSR assurance (before King III implementation), the comparative figure for the top 200 companies was actually $8 \%$ and not $15 \%$. The original Ackers (2009) raw data that studied the top 200 companies, but reported only on the top 100 , revealed that only one (i.e. $1 \%$ ) of the second hundred JSE-listed companies (i.e. from 101 to 200) provided independent CSR assurance.

In this study, 36 companies provided independent CSR assurance reports, (19\% of the sample by volume, but $57 \%$ by value). The JSE requirement for all listed companies to apply the provisions of the King III principles on an 'apply or explain' basis with effect from the financial years beginning 1 March 2010, makes the slow uptake of CSR assurance rather disconcerting. The market capitalisation of the companies providing CSR assurance confirms the slack resource proposition that larger companies have more 'slack resources' to invest in CSR-related issues (Bansal, 2005; Eccles et al., 2008; KPMG, 2011:11; Mill, 2006; Saleh, 2009). However, despite this slow uptake, this article suggests that as company CSR-related processes mature and as they improve their application of the King III principles, more companies will have their CSR reports independently assured, instead of continually explaining why they did not.

This study revealed that auditor assurors remained the dominant providers of independent CSR assurance in South Africa, collectively issuing 26 (72\%) assurance reports - of which 25 (69\%) were by the Big 4 audit firms. These auditor assuror reports included a joint CSR assurance report by two Big 4 firms; another where a Big 4 CSR assurance report was combined with an expert opinion; and one (3\%) by a mid-tier audit firm. Other providers of CSR assurance reports included seven $(20 \%)$ by consultants, two $(6 \%)$ by certification bodies and even one (3\%) by an internal audit activity. Unlike the Ackers (2009:11) study, where the only CSR assurors were the Big 4 firms (80\%) and consultants (20\%), this study established that the CSR assuror base and distribution has since broadened. In this regard, the South African CSR assurance market appears to be consolidating amongst the three major types of CSR assurors, mirroring the results of the CorporateRegister (2008:40) study.

Pertinent aspects of the respective characteristics of CSR assurance practices by the four assurors identified in this study are discussed below.

\subsection{Assurance standards}

Unsurprisingly, in this study, all 26 CSR assurance reports issued by auditor assurors referred to ISAE 3000, with one Big 4 firm even referencing both ISAE 3000 and AA100AS. Whereas no standard was referenced by the internal audit activity, and one certification body referenced both ISO19001 and ISAE 3000, the remaining 8 non-auditor assurors all referenced AA1000AS. In summary, $75 \%$ of assurance reports referenced ISAE 3000 , 25\% referenced AAI000AS, $3 \%$ 
referenced IS019001, one did not reference any standard, and 3\% referenced more than one standard. By comparison, CorporateRegister (2008:13) found that $31 \%$ of assurors referenced AA1000AS, 37\% referenced ISAE $3000,28 \%$ did not reference any standard, and $36 \%$ referenced more than one standard. Manetti and Becatti (2009) found that 44\% referenced ISAE 3000, $13 \%$ referenced AA1000AS, 28\% referenced both ISAE 3000 and AA1000AS, 22\% referenced other criteria, and $26 \%$ referenced more than one standard. The South African study (Ackers, 2009:9) found that $73 \%$ referenced ISAE 3000 and $45 \%$ referenced AA1000AS with $73 \%$ referencing more than one standard. While it is clear that the various standards are not mutually exclusive, with some assurors referencing more than one standard, this study reveals that the trend in South Africa since 2008/9 appears to be changing, especially with regard to the less frequent referencing of multiple standards.

The observation that ISAE 3000 was the primary standard used in CSR assurance engagements is consistent with the finding that auditor assurors were the dominant providers of independent CSR assurance, which is mandatory for members of the audit profession.

\subsection{Assurance report title}

Despite identifying four different types of independent assurors, no assuror prescribes a specific title for their CSR assurance reports. The study revealed that even the same type of assuror used different terms to describe their assurance reports. While most auditors disclose 'independent' in the title of the report, others reflect their independence in the report body. Despite the IFAE clearly distinguishing between auditing and assurance engagements (Al-Hamadeen, 2007:141), two CSR assurance reports issued by Big 4 audit firms were specifically titled 'report of the independent auditors ...' and 'independent audit report - non-financial', respectively. A title increasingly being used (especially by auditor assurors) is 'independent assurance report ...', which provides a comprehensive picture of the assurance objective and report content. Other titles used include 'assurance report', 'sustainability assurance statement', 'independent assurance statement', 'independent third party assurance statement' and 'independent assuror's report'. In this regard, it is clear that assuror independence is beginning to feature more prominently in the title of CSR assurance reports.

\subsection{Assurance report users}

The assurance reports issued by the internal audit activity and by one certification body, did not identify any intended users. The remaining certification body and the specialist CSR assurors addressed their assurance reports jointly to the board of directors and to the stakeholders. By contrast, auditor assurors did not address their assurance reports to their stakeholders, but to their principals as represented by the board, the directors, the members, the shareholders or even the company itself. It is suggested that this practice may be due to a combination of potential assuror's liability, general auditor conservatism, and the inertia of the audit profession resulting from AFS audit practice.

\subsection{Assurance liability}

This study observed that CSR assurance reports typically issued by the Big 4 audit firms include a statement disclaiming any liability arising from non-intended users placing reliance on the assured CSR report. However, this practice is inconsistent, with the assurance reports of one Big 4 audit firm and even signed by the same audit partner not always including a similar 
exclusionary paragraph. Moreover, the mid-tier auditor and none of the non-auditor assurors disclaim their liability in a similar manner. ICAEW, however (2008:19-20), cautions that despite auditor assurors attempting to confine their responsibility to their principals, they may still risk legal action from non-intended users. Terms used to exclude third-party liability include 'we do not accept or assume liability to any party other than the company ...'; 'we do not accept or assume responsibility to anyone other than the directors of the company and the company ...'; and 'we disclaim any assumption of responsibility ... to any person other than the directors or management ...'

It is therefore posited that this Big 4 audit firm practice of limiting liability to their principals involves more than mere auditor conservatism and may be directly attributed to the perceived strength and credibility of the global consumer brands of the Big 4 audit firms, possible assuror liability and the extent of exposure that their legal departments will allow. It is predicted that this trend will continue into the future, as audit firms, and especially the Big 4, strive to protect the value of their brands.

\subsection{Assurance recommendations}

AA1000AS specifically requires CSR assurors to include recommendations for improvement in a publicly issued assurance report, whereas ISAE 3000 is silent thereon. Manetti and Becatti (2009) found that $59 \%$ of assurors provided recommendations, but argued that assurors should restrict their opinions to the veracity of CSR disclosures, and refrain from consulting by providing advice.

In this study, all non-auditor assurors and one Big 4 audit firm (i.e. ten assurors - 28\%) included recommendations for improvement in their CSR assurance reports. However, in order to add value to their client companies and to reduce the perception of auditing being a 'grudge purchase', external auditors usually produce a management report that includes the auditor's detailed findings and provides recommendations for improvement. However, this management report is usually intended for internal stakeholder use only and is not available for public consumption. While not specifically covered in the scope of this article, the partners/directors responsible for CSR assurance at several audit firms confirmed producing similar reports for CSR-related engagements.

\subsection{Assurance opinions and levels}

It may be argued that the most important component of an assurance engagement is the assurance opinion provided in the assurance report. By expressing a clear and unambiguous opinion about the veracity of the underlying CSR disclosures, assurors enhance report credibility (Al-Hamadeen, 2007:187; AccountAbility, 2008:23). When the engagement results and opinions are not clearly communicated in the assurance report, stakeholders cannot meaningfully evaluate and compare the underlying CSR disclosures (Ackers, 2009:11-12; Manetti \& Becatti, 2009). Assurance opinions may be unqualified, qualified or disclaimed, but should be informed and supported by verifiable evidence and clearly articulated in the assurance report (CorporateRegister, 2008:22). The precise meaning of the assurance opinion provided by an assurance report is directly linked to the level of assurance provided. Therefore, disclosing the assurance level improves users' understanding of the engagement risk and circumstances, and indicates the extent of reliance that may be placed on the underlying CSR report (Al-Hamadeen, 2007:146). 
Whereas ISAE 3000 requires assurors to provide 'reasonable assurance' for objectively verifiable aspects, 'limited assurance' for more complicated verifiable aspects, or a combination thereof (Manetti \& Toccafondi, 2012; Wiertz, 2009:43-44), AAl000AS requires assurors to provide 'moderate' or 'high' assurance levels, or a combination of the two (AccountAbility, 2008:9-10). Despite referring to fundamentally different assurance levels, the difference in the wording of reasonable and limited assurance opinions is so discrete that it is extremely difficult for uninformed users to discern the difference. Positive-form reasonable assurance opinions are usually worded as 'in our opinion, internal control is effective ...', whereas negative-form limited assurance opinions are worded as 'nothing has come to our attention that causes us to believe that internal control is not effective ...' Whereas reasonable assurance opinions indicate that the evidence confirms that the underlying information is reliable, limited assurance opinions may imply that while insufficient work has been performed to allow the assuror to conclude that the underlying disclosures are reliable, at the same time it may indicate that there is no reason why the results should not be as expected.

Consultants typically provide higher assurance levels than auditor assurors (Owen \& 0'Dwyer, 2004:26). Non-auditor assurors usually provide positively framed reasonable assurance opinions, whereas auditor assurors tend to provide negatively framed limited opinions, as illustrated by:

- CorporateRegister (2008:16) finding that $83 \%$ of auditor assurors provided limited assurance; $73 \%$ of consultants provided reasonable assurance; and $92 \%$ of certification bodies provided reasonable assurance.

- Manetti and Becatti's (2009) finding that $59 \%$ of assurance reports provided limited assurance, $9 \%$ provided reasonable assurance and the remaining $32 \%$ provided a combination of reasonable and limited assurance.

- Ackers's (2009) finding that all consultants provided reasonable assurance and $67 \%$ of auditor assurors provided limited assurance, with $25 \%$ providing reasonable assurance for certain aspects of the CSR report, limited assurance for some and disclaimers for others.

This research found that all auditor assurors provided negatively framed limited assurance, including $22 \%$ who provided limited assurance on some aspects of the CSR report and reasonable assurance on others. However, the internal audit activity did not specify an assurance level. By comparison, all non-auditor assurors provided reasonable assurance opinions, including one certification body, which, despite referencing ISAE 3000, provided a reasonable assurance opinion, worded as follows: '.. in all material respects, the following topics are appropriately reported ...' Other non-auditor assuror opinions were typically worded as: 'provides a fair summary ...'; 'confident that this report provides a comprehensive and balanced account ...'; '... is free from material misstatement'; or '... the report has been prepared according to ...' Since it may be argued that positively framed reasonable assurance opinions provide CSR report users with greater confidence about the veracity of the underlying CSR disclosures than negatively framed limited assurance opinions, this study clearly reveals that auditor conservatism produces lower assurance levels than non-auditors.

\section{LIMITATIONS AND RECOMMENDATIONS FOR FUTURE RESEARCH}

Although not specifically examined in this study, it is posited that the growth of CSR assurance by auditors was likely to result from other attributes of the auditing profession, including its 
perceived credibility and its strong professional brand, the Big 4 audit firms in particular (especially in South Africa). This positive association with the audit profession is enhanced by utilising a rigorous assurance methodology that has been carefully honed over time (Ackers, 2009). Similarly, despite not being specifically examined, it is asserted that the faster growth in CSR assurance by non-auditors may be due to the reporting companies' perspective that the credibility and brand of the audit profession do not add sufficient value to their CSR assurance process to offset the costs of the premium usually paid to the Big 4 audit firms, and not necessarily due to the higher assurance levels provided by non-auditor assurors. It is accordingly recommended that additional research should be conducted to determine the validity of these unverified assertions.

\section{CONCLUSION}

This article argues that reporting companies should provide stakeholders with independent assurance on their CSR disclosures. This should assist in bridging the credibility gap between company CSR disclosures and the legitimate expectations of stakeholders, while at the same time ameliorating the risk of green-wash. This study examined the CSR assurance phenomenon within the context of the various CSR assurors, the different assurance standards utilised, the components of the CSR assurance report, and the prevalence of CSR assurance in JSE-listed companies.

Despite this exploratory study establishing that the primary CSR assurors active in South Africa were representatives of the auditing profession (primarily the Big 4 audit firms), consultants and certification bodies, this study considers the CSR assurance characteristics of the auditing profession. While ISAE 3000 and AA1000AS were the primary assurance standards used by the CSR assurors of JSE-listed companies, the selection of the assurance standard used was influenced by whether the assurance provider was an auditor assuror or a non-auditor assuror. This article examined and discussed CSR assurance reports in the context of the assurance levels and opinions provided and considered their implications for stakeholders placing reliance thereon.

Even though Manetti and Becatti (2009) expected the auditor's CSR assurance role to develop rapidly following the release of ISAE 3000 , it is reiterated that ISAE 3000 is a generic nonfinancial assurance standard that has not been specifically designed to provide assurance on CSR disclosures (Ackers, 2009; FEદ, 2006; Manetti \& Becatti, 2009). It may therefore be argued that AA1000AS is a more appropriate CSR assurance standard since it was specifically developed for CSR assurance. This article however contends that despite the CSR assurance role of the audit profession expected to increase in the future, it is suggested that this growth will be constrained by the requirements of the IFAE and the lack of a dedicated CSR assurance standard applicable to the auditing profession. When compared to the Ackers (2009) study, the impact of this constraint is illustrated by this study finding that despite the increase in CSR assurance provided by the audit profession the rate of CSR assurance growth by auditor assurors was slower than that of non-auditor assurors.

In conclusion, this study has revealed that the diversity of assurors, assurance standards, assurance approaches and assurance levels are unlikely to clearly indicate the extent of reliance that users may place on the different CSR assurance reports. It is accordingly suggested that in order to ameliorate the existing report user confusion through effective stakeholder engagement, reporting companies and various CSR assurors should work together to develop a universally accepted and comparable assurance standard. Moreover, it is predicted that 
notwithstanding the audit profession's impeccable credibility, by continuing its present CSRrelated intransigence and failing to adopt a more proactive CSR assurance role, the CSR assurance role of the audit profession will continue to be eroded by non-auditor assurors. Unless a definitive CSR assurance standard applicable to auditor assurors is developed to obviate using the generic ISAE 3000 standard for CSR assurance engagements, other disciplines are likely to usurp the auditing profession's present dominant role in developing the engagement criteria for CSR assurance (ICAEW, 2004:5). This intransigence may even result in a reduction of involvement by the audit profession in key business growth areas such as strategic planning, statutory requirements, taxation, internal and external and external reporting (ICAEW, 2004:5).

\section{LIST OF REFERENCES}

Ackers, B. (2009). Corporate social responsibility assurance: how do South African publicly listed companies compare? Meditari Accountancy Research, 17(2), pp. 1-17.

AccountAbility (2008). AA1000AS Assurance Standard. Accountability, London, UK.

Adams, C. \& Evans, R. (2004). Accountability, completeness, credibility and the audit expectations gap. Journal of Corporate Citizenship, 14, pp. 97-115.

Al-Hamadeen, R.M. (2007). Assurance of corporate stand-alone reporting: evidence from the UK. Unpublished PhD thesis. St. Andrews, Scotland, UK: University of St. Andrews.

Alves, I. (2009). Green Spin Everywhere: How Green-wash Reveals the Limits of the CSR Paradigm. Journal of Global Change and Governance, 1(1), pp. 1-26.

Aras, G. \& Crowther, D. (2008). Corporate Sustainability Reporting: A Study in Disingenuity? Journal of Business Ethics, 87(1), pp. 279-288.

Ashbaugh, H. (2004). Ethical issues related to the provision of audit and non-audit services: evidence from academic research. Journal of Business Ethics, 52, pp. 143-148.

Bansal, P. (2005). Evolving sustainability: A longitudinal study of corporate sustainable development. Strategic Management Journal, 26, pp. 197-218.

Blair, M.M. (2005). Closing the Theory Gap: How the Economic Theory of Property Rights Can Help Bring 'Stakeholders' Back into Theories of the Firm. Journal of Management and Governance, 9, pp. 33-39.

Brown, R.G. (1962). Changing Audit Objectives and Techniques. The Accounting Review, 37(4), pp. 696-703.

Cascarino, R.E. \& van Esch, S.D. (2007). Internal Auditing - An Integrated Approach. $2^{\text {nd }}$ edition. Juta, Lansdowne, South Africa.

Chandler, R. \& Edwards. J.R. (1996). Recurring issues in auditing: back to the future? Accounting, Auditing \& Accountability Journal, 9(2), pp. 4-29.

CorporateRegister (2008). The CSR Assurance Statement Report. CorporateRegister, London, UK.

Dando, N. \& Swift, T. (2003). Transparency and assurance: Minding the credibility gap. Journal of Business Ethics, 44(2-3), pp. 195-200.

Davis, K. (1960). Can business afford to ignore social responsibilities? California Management Review, 2(3), pp. 70-77. 
Davis, K. (1973). The Case for and Against Business Assumptions of Social Responsibilities. Academy of Management Journal, 16(2), pp. 50-66.

Deegan, C., Cooper, B. \& Shelly, M. (2006). An investigation of TBL report assurance reports: UK and European evidence. Managerial Auditing Journal, 21(4), pp. 329-371.

Delmas, M.A. \& Burbano, V.C. (2011). The Drivers of Green-wash. California Management Review, 54(1), pp. 64-87.

Deloitte (2012). Integrated Reporting - Navigating your way to a truly Integrated Report, $2^{\text {nd }}$ edition. Deloitte, Johannesburg, South Africa.

Eccles, R.G. (2010). Introduction: The state of integrated reporting today. In Eccles, R.G., Cheng, B. \& Saltzman, D. (eds.) The landscape of integrated reporting - Reflections and next steps. Harvard Business School, Cambridge, Massachusetts, USA (pp. iii-xii).

Eccles, N.S., Pillay, V. \& de Jongh, D. (2008). Correlates of corporate accountability amongst South Africa's largest listed companies. Southern African Business Review, 13(1), pp. 21-38.

Eccles, R.G., Krzus, M.P. \& Watson, L.A. (2012). Integrated reporting requires integrated assurance. In Oringel, J. (ed.) Effective auditing for corporates: key developments in practice and procedures. Bloomsbury Information Ltd., London, UK (pp. 161-178).

Fédération des Experts Comptables Européens (Federation of European Accountants) (FEદ) (2003). Benefits of sustainability assurance. $\mathrm{FEE}$, Brussels, Belgium.

Fédération des Experts Comptables Européens (Federation of European Accountants) (FE६) (2006), FEE calls for sustainability audit standard. Accountancy, 137(1355), pp. 85.

Fédération des Experts Comptables Européens (Federation of European Accountants) (FE६) (2011). Environmental, social and governance (ESG) indicators in annual reports - an introduction to current frameworks. FEદ, Brussels, Belgium.

Freeman, R.E. (1994), The Politics of Stakeholder Theory: Some Future Directions. Business Ethics Quarterly, 4(4), pp. 409-421.

Friedman, M. (1970). The Social Responsibility of Business is to Increase its Profits. The New York Times, 13 September, 1970.

Gouws, D.G \& Cronjé, C.J. (2008). Corporate annual reports: accounting practices in transition. Southern African Business Review, 12(2), pp. 108-132.

Haniffa, R. \& Hudaib, M. (2007). Locating Audit Expectation Gap within a Cultural Context: The Case of Saudi Arabia. Journal of International Accounting, Auditing and Taxation, 16, pp. 179-206.

Institute of Chartered Accountants in England and Wales (ICAEW) (2004). Information for Better Markets - Sustainability: the role of accountants. ICAEW, London, UK.

Institute of Chartered Accountants in England and Wales (ICAEW) (2008). Assurance on non-financial information - existing practices and issues. ICAEW, London, UK.

Institute of Directors (IOD) (2009). King Code of Governance for South Africa 2009. LexisNexis, Sandton, South Africa.

Institute of Internal Auditors (IIA) (2010). Evaluating Corporate Social Responsibility/Sustainable Development. IPPF - Practice Guide. IIA, Altamonte Springs, Florida, USA.

International Federation of Accountants (IFAC) (2006). Assurance Aspects of G3 - The Global Reporting Initiative's 2006 Draft Sustainability Reporting Guidelines. IFAC. 
Jackson, R.D.C. \& Stent, W.J. (2012). Auditing Notes for South African Students, $8^{\text {th }}$ Edition. Audit Education, Durban, South Africa.

Jenkins, R. (2001). Corporate Codes of Conduct: Self-Regulation in a Global Economy. United Nations Research Institute for Social Development (UNRISD), Geneva, Switzerland. (Technology, Business and Society, Programme Paper no. 2, April 2001).

Johannesburg Stock Exchange (JSE) (2011). JSE listing requirements, service issue 14. JSE. Available: http://www.jse.co.za/Libraries/JSE____Listings_Requirements_-

_Service_Issues/Service_Issue_14.sflb.ashx. (Accessed 28 January 2012).

Kirdahy, M. (2007). Responsibility Pays. Forbes.com. Available:

http://forbes.com/leadership/2007/11/12/corporate-philanthropy-projects-lead-ci. (Accessed 30 July 2008).

Kirk, R. (2008), The Old Future is Gone. Forbes.com. Available:

http://www.forbes.com/2008/01/04/environment-kirk-corporate-lead-citizen-

cx_vk_0104sustainability.html?partner=relatedstoriesbox. (Accessed 3 March 2008).

Kok, P., van der Wiele, T., McKenna, R. \& Brown, A. (2001). A Corporate Social Responsibility Audit within a Quality Management Framework. Journal of Business Ethics, 31, pp. 285-297.

Kolk, A. \& Perego, P. (2010). Determinants of the adoption of sustainability assurance statements: an international investigation. Business Strategy and the Environment, 19, pp. 182-198.

KPMG (2011). KPMG Internationa/ Survey of Corporate Responsibility Reporting 2011. KPMG Sustainability Services, Amsterdam, the Netherlands.

Lin, Z.J. \& Chen, F. (2004). An Empirical Study of Audit 'Expectation Gap' in The People's Republic of China. International Journal of Auditing, 8, pp. 93-115.

Lyon, T.P. \& Maxwell, J.W. (2011). Green-wash: corporate environmental disclosure under threat of audit. Journal of Economics \& Management Strategy, 20(1), pp. 3-41.

Manetti, G. \& Becatti, L. (2009). Assurance Services for Sustainability Reports: Standards and Empirical Evidence. Journal of Business Ethics, 87(1), pp. 289-298.

Manetti, G. \& Toccafondi, S. (2012). The role of stakeholders in sustainability reporting assurance. Journal of Business Ethics, 107(3), pp. 363-377.

Manwaring, T. \& Spencer, R. (2009), Beyond Accounting - assessing the impact of sustainability reporting on tomorrow's business. Foreword to a soft launch of the project and a discussion paper authored by Graham Hubbard of Adelaide University. Available:

http://www.forceforgood.com/Uploaded_Content/tool/14120101364110.pdf. (Accessed 17 January 2011)

Marx, B. \& van Dyk, V. (2011). Sustainability reporting and assurance: An analysis of assurance practices in South Africa. Meditari Accountancy Research, 19(1/2), pp. 39-55.

Maury, M.D. (2000). A Circle of Influence: Are all Stakeholders included? Journal of Business Ethics, 23, pp. 117-121.

McAusland, S \& Fogelberg, T. (2010). Dealing With Climate Change Is Up To Companies, Not Just Governments. Forbes. Available: http://www.forbes.com/2010/04/12/climate-change-warmingleadership-citizenship-environment.html?partner=alerts. (Accessed 13 April 2010).

Mill, G.A. (2006). The financial performance of a socially responsible investment over time and a possible link with corporate social responsibility. Journal of Business Ethics, 63, pp. 131-148. 
Mitchell, C.G. \& Hill, T.R. (2010). An exploratory analysis of stakeholders' expectations and perceptions of corporate social and environmental reporting in South Africa. Southern African Journal of Accounting Research, 24(1), pp. 49-78.

Morimoto, R., Ash, J. \& Hope, C. (2005). Corporate Social Responsibility Audit: from Theory to Practice. Journal of Business Ethics, 62, pp. 315-325.

Nitkin, J. \& Brooks, L.J. (1998). Sustainability Auditing and Reporting: The Canadian Experience. Journal of Business Ethics, 17: pp. 1499-1507.

O'Dwyer, B. \& Owen, D. (2005). Assurance statement practice in environmental, social and sustainability reporting: perspectives of stakeholders in Ireland. The British Accounting Review, 37(2), pp. 205-229.

0'Dwyer, B., Owen, D. \& Unerman, J. (2011). Seeking legitimacy for new assurance forms: the case of assurance on sustainability reporting. Accounting, Organisations and Society, 36, pp. 31-52.

Okoye, A. (2009). Theorising Corporate Social responsibility as an Essentially Contested Concept: is a Definition Necessary? Journal of Business Ethics, 89, pp. 613-627.

Orlitzky, M., Schmidt, F.L. \& Rynes, S.L. (2003). Corporate social and financial performance: A metaanalysis. Organisation Studies, 24(3), pp. 403-441.

Owen, D. \& O'Dwyer, B. (2004). Assurance statement quality in environmental, social and sustainability reporting: a critical evaluation of leading edge practice. International Centre for Corporate Social Responsibility, Nottingham University Business School, UK. (No. 23-2004 ICCSR Research Paper Series - ISSN 1479-5124.

Owen, D.L., Swift, T.A., Humphrey, C. \& Bowerman, M. (2000). The new social audits: accountability, managerial capture or the agenda of social champions? The European Accounting Review, 9(1), pp. $81-98$.

Peecher, M.E., Solomon, I. \& Trotman, K. (2010). Improving the Quality of Financial-Statement Audits by Updating External Auditors' Accountabilities. Working paper series. Available:

http://papers.ssrn.com/sol3/papers.cfm?abstract_id=1692322. (Accessed 14 March 2013).

Percy, J.P. (1997). Auditing and Corporate Governance - a Look Forward into the $21^{\text {st }}$ Century. International Journal of Auditing, l(1), pp. 3-12.

Perego, P. (2009). Causes and Consequences of Choosing Different Assurance Providers: An International Study of Sustainability Reporting. International Journal of Management, 26(3), pp. 412-425.

Polonsky, M.J., Landreth, S. \& Garma, R. (2010). The New Green-wash? Potential Marketing Problems with Carbon Offsets. International Journal of Business Studies, 18(1), pp. 49-54.

Porter, B., Simon, J. \& Hatherly, D. (2003). Principles of External Auditing, $2^{\text {nd }}$ Edition. John Wiley \& Sons, Chichester, West Sussex, England.

Ramasamy, B. \& Yeung, M. (2009), Chinese Consumers: Perception of Corporate Social responsibility. Journal of Business Ethics, 88(1), pp. 119-132.

Saleh, M. (2009). Corporate social responsibility disclosure in an emerging market: A longitudinal analysis approach. International Business Research, 2(1), pp. 134-141.

South African Institute of Chartered Accountants (SAICA) (2008). SAICA Handbook Volume 2A, 2008/2009, Auditing. SAICA, Johannesburg, South Africa. 
South African Institute of Chartered Accountants (SAICA) (2010), Code of professional conduct for Chartered Accountants. SAICA, Johannesburg, South Africa.

Swift, T. \& Dando, N. (2002). From methods to ideologies: closing the assurance expectations gap in social and ethical accounting, auditing and reporting. Journal of Corporate Citizenship, 8, pp. 81-90.

Teoh, H.Y. \& Shiu, G.Y. (1990). Attitudes towards corporate social responsibility and perceived importance of social responsibility information characteristics in a decision context. Journal of Business Ethics, 9, pp. 71-77.

Utting, P. (2005). Beyond Social Auditing: Micro and Macro Perspectives. Proceedings of the $\varepsilon U$ Conference on 'Responsible Sources: Improving Global Supply Chains Management', 18 November, Brussels, Belgium.

Votaw, D. (1972). Genius Becomes rare: A Comment on the Doctrine of Social Responsibility, Part 1. California Management Review, 15(2), pp. 25-31.

Welman, C., Kruger, F. \& Mitchell, B. (2011). Research Methodology, $3^{\text {td }}$ edition, $10^{\text {th }}$ impression. 0xford University Press Southern Africa, Goodwood, South Africa.

Wiertz, J.H.L. (2009). Assurance statement practices in CSR reporting: an international approach. Unpublished M.Sc. Thesis. Maastricht, The Netherlands: Maastricht University.

Williams, G. \& Zinkin, J. (2008). The Effect of Culture on Consumer Willingness to Punish Irresponsible Corporate Behaviour: Applying Hofstede's Typology to the Punishment Aspect of Corporate Social Responsibility. Business Ethics: A European Review, 17(2), pp. 210-226.

Wood, D.J. (1991). Corporate Social Performance Revisited. Academy of Management Review, 16(4), pp. 691-718. 